\title{
Firm- and Country-Level Drivers of Capital Structure: Quantitative Evidence from Central and Eastern European Listed Companies
}

\author{
Diana A. TOADER, Georgeta VINTILA and Stefan C. GHERGHINA \\ Bucharest University of Economic Studies, Bucharest, Romania
}

Correspondence should be addressed to: Diana A. TOADER; diana.tda29@gmail.com

Received date: 6 May 2021; Accepted date:23 August 2021; Published date: 20 January 2022

Copyright (C) 2022. Diana A. TOADER, Georgeta VINTILA and Stefan C. GHERGHINA. Distributed under Creative Commons Attribution 4.0 International CC-BY 4.0

\begin{abstract}
This paper aims to investigate the determinants of capital structure in developing countries, like Romania, Bulgaria and Hungary. This research adopts the unbalanced panel data of 152 listed companies, over the period 1996-2020, estimated by two-stage least squares. This paper covers several firm-specific variables (profitability, return on assets, liquidity, size, growth, free cash flow), country-specific variables (gross domestic product growth and inflation) and institutional factors (rule of law, control of corruption and government effectiveness). Our main findings show that profitability and liquidity have negative correlations with leverage. In addition, selected institutional factors have a direct impact on capital structure, whereas for macroeconomic variables the results are mixed.
\end{abstract}

Keywords: Capital structure, Emergent Countries, Institutional factors, Two-stage least squares

\section{Introduction}

Economic cycles in the last decades suffered a lot of changes, defined by booms and recessionary phases. These dynamics affect the value of a firm, which is characterized by investments. In order to finance these investments, it is important to find an optimal financial mix. Financial decisions are crucial to the economic welfare of the firm, as wrong decisions regarding balance of the capital structure may lead to financial distress, eventually to bankruptcy. Optimal capital structure emphasizes a fusion between equity and debt and represents the foundation of a healthy development of the firm. It is necessary to maximize the shareholder's wealth, ultimately the firm's value. Therefore, capital structure is one of the major issues of concern for a firm and

Cite this Article as: Diana A. TOADER, Georgeta VINTILA and Stefan C. GHERGHINA (2022)," Firm- and Country-Level Drivers of Capital Structure: Quantitative Evidence from Central and Eastern European Listed Companies", Journal of Financial Studies \& Research, Vol. 2022 (2022), Article ID 572694,

DOI: $10.5171 / 2022.572694$ 
generally in corporate finance. Thus, it is essential to know about the factors influencing the financial decision of a firm. Capital structure determinants serve as key indicators and at the same time represent competitive advantage to a company.

Since the work of Modigliani and Miller (1958), various theories have been undertaken to improve their model, which support the principle of irrelevancy in a perfect market, more accurate that capital structure has no impact on the firm's value. Their model raised many criticisms due to lack of applicability and in their following paperwork they take into consideration corporate taxes, suggesting that a firm's value is maximized through tax deductibility of debt. To examine the financial structure of a firm, several theories have been developed, namely Trade-off theory (Kraus and Litzenberger, 1973; Bradley, Jarrell and Kim, 1984; Kane, Marcus and McDonald, 1984; Fama and French, 2002), Pecking order theory (Stiglitz, 1973; Frank and Goyal, 2003; Goyenko, Holden and Trzcinka, 2009), Agency costs theory (Jensen and Meckling, 1976), Market timing theory (Baker and Wurgler, 2002), Signaling theory (Ross, 1977).

The choice of external financing is highlighted by two opposite theories: trade off theory and pecking order theory. Trade off theory suggests that there is a balance between the cost of financial distress and the costs of debt. According to pecking order theory, companies can use an order of hierarchical financing (Myers and Majluf, 1984). In other empirical studies, researchers consider that macroeconomic indicators can also explain the use of debt (Booth et al, 2001; Mazur, 2007; Frank and Goyal, 2009). Some studies consider that the effects of firm specific factors are similar in each country (Booth et al, 200; Giannetti, 2003). Recently, studies that cover countries in Europe and the United States found that international operations and the environment of institutions have an important influence on the financial decision (De Jong et al, 2008; Brounen et al, 2006).
This study aims to extend the literature by analyzing the determinants of capital structure in three emergent countries ( Romania, Bulgaria and Hungary). The explanatory variables included in this paper refer to profitability, liquidity, risk, tax, macroeconomic and institutional indicators. Using panel data regression, we concluded that the explanatory variables affect the capital structure of the companies. The empirical results imply that trade-off theory and pecking order theory partially explain the financial decisions made by organizations. This study is organized as follows: The next section presents the theoretical background. The following section contains the presentation of the variables and methodology. The subsequent section presents and discusses the results of the empirical analysis. The last section summarizes the findings of this research and presents the conclusion of this study.

\section{Theoretical Framework}

The corporate finance literature is very comprehensive, but only two theories proved to be relevant in explaining the financial decision, namely, trade-off theory and pecking order theory. From the perspective of trade-off theory, the optimal level of debt is reached when there is a balance between the marginal benefit of debt (tax deductibility of interest expenses) and its marginal cost (Myers, 2001). Higher debt implies higher interest rates and bankruptcy costs. In this regard, companies can accomplish an ideal capital structure by alternating between debt and equity. This theory does not take into consideration agency costs, pecking order or information asymmetry (Bradley et al. 1984). It considers that every company has an ideal debt level and the first decision when a firm needs more capital is to make a trade off between the costs and benefits of debt use. In opposition to trade off theory, pecking order theory rejects the principle of existing of an ideal debt level and it is based on the existence of information asymmetry between managers, creditors and shareholders. This theory argues that companies should follow a pecking order, meaning using first internal funds, then debt issuance and ultimately equity offering (Myers and Majluf, 1984). 
Over the years, many paperworks studied the determinants of capital structure. The association between the influence factors and capital structure is made according to the theories mentioned above. However, Harris and Roark (2019), for example, illustrate that there is no model to identify the determinants of the capital structure choice. Previous studies used different measures of capital structure. In this paper, we use total debt to total assets ratio, the most utilized measure (Frank and Goyal, 2009), and total debt to equity ratio. As explanatory variables, we use the most representative firm-specific variables identified in the literature (Rajan and Zingales, 1995; Baker and Wurgler, 2002) as profitability, size, risk, liquidity, growth opportunities. Country specific variables and institutional factors were also included, based on previous studies (La Porta et al. 1998; Demirguc-Kunt and Maksimovic, 1998; Booth et al. 2001). Therefore, the following variables are tested in our model:

\section{Profitability}

According to trade-off theory, profitable companies should have more leverage and less bankruptcy risk. They tend to borrow long term debt in order to take advantage of tax shields and the creditors also tend to fund these firms. (Frank and Goyal, 2003; Vo, 2017). Thus, this theory predicts a positive relationship between profitability and leverage (Margaritis and Psillaki, 2007). Contrary, pecking order theory suggests that companies with high profitability tend to use retained earnings rather than external financing, therefore they will have smaller debt ratios. Based on this theory, there is a negative relationship between profitability and debt (Fama and French, 2002; Moradi and Paulet, 2019). Lemmon and Zender (2010) showed that firms prefer to use first external debt instead of equity issuance and affirm that this theory explains better the financing decisions of firms.

\section{Liquidity}

Generally, empirical findings have shown that liquidity variables have a mixed impact on capital structure decisions. According to trade-off theory, firms with enough liquidity can choose debt as financing source, because they have the ability to meet their obligations (Vo, 2017). Thereby, this theory states that there is a positive relationship between liquidity and debt. On the other hand, pecking order theory suggests that companies with high liquidity require less external financing and they are able to use internal funds to finance their operations and investments (Eriotis et al. 2007; Eldomiaty and Azim, 2008; Khemiri and Noubbigh, 2018).

\section{Size}

Large-sized companies have less risk of bankruptcy, a diversified portfolio and lower variance of earnings, and that makes them more tolerant with high debt ratios (Titman and Wessels, 1988). According to trade-off theory, there is a direct impact between firm's size and debt. Many researchers obtained a postive relationship between size and capital structure (Eriotis et al. 2007; Ezeoha, 2008). In contrast, pecking order theory highlights that big companies have the ability to finance their investments through internal funds or through equity issuance (Marsh, 1982). In case of large firms appears the problem of greater information asymmetry and therefore lower chance to attract debt. Thus, this theory predicts a negative relationship between size and debt (Deloof and Overfelt, 2008). Further, Karadeniz et al. (2009) obtained in their study an insignificant relationship between size and capital structure.

\section{Growth}

Trade-off theory predicts a negative relationship between growth opportunities and leverage (De Jong et al. 2008; Ooi, 1999; Antoniou et al. 2008). Rajan and Zingales (1995) obtained an inverse relationship too and they stated that growing firms will choose to finance their decisions through equity and less through debt. Moreover, this decision comes with less information asymmetry. The results of other paperworks revealed a positive relationship between growth opprotunities and debt (Amidu, 2007; Chen, 2004; Heshmati, 2001). Pecking order theory predicts a positive relationship between growth opportunities and leverage. Based on this theory, growing firms take into consideration the use of internal funds with 
priority. Eriotis et al. (2007) and Karadeniz et al. (2009) obtained an insignificant relationship in their research.

\section{Risk}

Risky firms should not have high debt ratios according with trade-off theory (Titman and Wessels, 1988), thus, between risk and debt exists a negative association (Eldomiaty, 2007). Companies with great volatility in earnings have more chances to go bankrupt and at the same time they have redit-worthiness. Viviani (2008) and Ezeoha et al. (2011) confirm in their research the absence of a relationship between risk and debt.

\section{Effective tax rate}

A positive relationship is expected between effective tax rate and debt, based on tradeoff theory (Graham, 1996; DeAngelo and Masulis, 1980). A company with high corporate tax will borrow more to maximize the benefit of tax deduction of the debt interest, rather than other financing sources such as equity issuance (Modigliani and Miller, 1963). Other researchers concluded that there is a negative relationship between effective tax rate and debt ratios (Karadeniz et al. 2009), Antoniou et al. (2008), affirming that the correlation between effective tax rate and capital structure depends on tax regulation in each country. Huang and Song (2006) demonstrated that there is no relationship between this tax and debt.

\section{Gross domestic product growth}

It is assumed that gross domestic product growth affects the capital structure decisions of firms. The increase of growth rate sends a good signal to companies, encouraging them to use more external financing, either through banks or capital market (Demirguc-Kunt and Maksimovic, 1998; Cheng and Shiu, 2007). The development of banking system and stock markets affect the capital structure decisions too. As the stock markets develop, the cost of transactions is decreasing and companies are likely to choose equity issuance instead of debt (Fan et al. 2012). Similar, as the banking sector develops, the costs of borrowing are decreasing and companies are tended to choose debt financing through banks (Booth et al. 2001).

\section{Inflation}

High interest rates increase the cost of borrowing and the firms are discouraged to choose more debt as external financing; at the same time, creditors are also afraid to provide capital, because the risk increases too (Demirguc-Kunt and Maksimovic, 1998).

\section{Institutional factors}

Low institutional quality in emergent countries is characterized through limited capital markets, which makes it difficult for companies to access capital (La Porta et al. 1998). It is also challenging for firms to raise external debt. Companies which operate in countries with strong institutions and laws can raise external debt more faster (Demirguc-Kunt and Maksimovic, 1998). For example, laws which protect creditors' rights encourage lenders to provide capital to firms (Qian and Strahan, 2007). Fan et al. (2012) found in their paperwork that corruption, tax systems have a relevant impact on debt, for example in countries where companies can benefit from tax deduction through indebtness, there is more debt used as financing source. Jong et al.'s (2008) results showed that country-specific and insitutional factors affect firm specific determinants, which affect further the capital structure of the firm.

\section{Data And Methodology}

\section{Sample and measures}

The data set for this analysis is handcollected from Thompson Reuters and World Bank Group. Our sample consists of 152 nonfinancial companies from three developing countries: 45 firms from Hungary, listed on Budapest Stock Exchange; 78 firms from Romania, listed on Bucharest Stock Exchange; and 29 firms from Bulgaria, listed on Bulgarian Stock Exchange. The empirical analysis was achieved with an unbalanced panel data, over the period 1996-2020. The selected variables are reported in Table 1. 
Table 1: Description of selected variables

\begin{tabular}{|c|c|}
\hline Variable & Definition \\
\hline \multicolumn{2}{|r|}{ Dependent variable } \\
\hline TDTE & Total Debt/Total Equity \\
\hline TDTA & Total Debt/Total Assets \\
\hline \multicolumn{2}{|r|}{ Firm specific variables } \\
\hline FCF & Free cash flow \\
\hline ROA & Return on assets \\
\hline SIZE & Firm's size - natural logarithm of total assets \\
\hline ETR & Effective tax rate \\
\hline GROWTH & Total revenue variation \\
\hline CURRENT_R & Current ratio \\
\hline QUICK_R & Quick ratio \\
\hline \multicolumn{2}{|r|}{ Country-specific variables } \\
\hline GDP_G & Gross domestic product growth (in percentage) \\
\hline \multirow[t]{2}{*}{ INF } & Inflation: annual inflation rate \\
\hline & Institutional factors \\
\hline ROF & Rule of law \\
\hline $\mathrm{CC}$ & Control of Corruption \\
\hline $\mathrm{GE}$ & Governance Effectiveness \\
\hline
\end{tabular}

Source: Authors' own work.

*Rule of law: reflects the perception of the extent to which agents have confidence in and abide by the rules of society (range from 0 to 100)

*Control of corruption: reflects perceptions of the extent to which public power is exercised for gain (range from 0 to 100)

*Governance Effectiveness: reflects perceptions of the quality of public services and the degree of its independence from political pressure (range from 0 to 100)

** Data description from World Bank Group

\section{Quantitive Methods}

In previous studies of capital structure determinants, we used different quantitative methods such as ordinary least squares, fixed effects panel regression and two-stage generalized method of moments to test the robustness of the models. In this research, the panel data analysis is performed by two-stage least squares. Generalized form of the regression is:

$$
\mathrm{LEV}_{\text {it }}=\alpha+\sum \beta_{\mathrm{i}} \mathrm{X}_{\mathrm{it}}+\varepsilon_{\mathrm{it}}
$$

Where:

LEVit represents the dependent variable and the leverage of company (i) to the period $(\mathrm{t})$.
The (i) subscript denotes the cross-section dimensions, whereas $(\mathrm{t})$ denotes the timeseries dimension.

$\alpha$ represents the intercept;

$\beta$ represents the coefficient for the $\mathrm{Xit}$ explanatory variable;

Xit represents independent variables;

$\varepsilon$ represents the error term;

\section{Empirical Findings}

\section{Univariate Analysis}

Table 2 below shows the descriptive statistics. The mean of total debt to total assets ratio is $19 \%$, while the mean of total debt to equity is $25 \%$. The highest gross domestic product growth is $10 \%$. The mean values of institutional factors show that the country's perception towards society rules, 
quality of public services and corruption, is neutral.

Table 2: Descriptive statistics

\begin{tabular}{|l|c|c|c|c|c|}
\hline & & & & & \\
\hline VARIABLES & Obs & Mean & Std.Dev & Min & Max \\
\hline & & & & & \\
\hline TDTA & 2,019 & 0.191 & 0.339 & 0 & 12.23 \\
\hline TDTE & 2,018 & 0.251 & 5.293 & -203 & 80.38 \\
\hline Current_r & 2,045 & 4.314 & 23.68 & 0.0100 & 750.4 \\
\hline Quick_r & 1,942 & 2.274 & 9.040 & 0.0100 & 262.8 \\
\hline ETR & 1,517 & 0.180 & 1.523 & -34.76 & 45 \\
\hline FCF & 1,963 & 9.501 & 79.45 & -396.2 & 1,460 \\
\hline ROA & 2,017 & 0.0387 & 1.077 & -5.443 & 47.57 \\
\hline Size & 2,018 & 3.631 & 1.694 & -4.605 & 9.705 \\
\hline Growth & 1,841 & 0.186 & 2.443 & -1 & 93.96 \\
\hline GDP_G & 2,039 & 3.231 & 3.452 & -6.700 & 10.43 \\
\hline Inf & 2,039 & 3.739 & 3.175 & -1.545 & 23.47 \\
\hline RoF & 2,035 & 59.29 & 7.976 & 46.04 & 82.78 \\
\hline CC & 2,035 & 54.85 & 6.081 & 40.40 & 77.84 \\
\hline GE & 2,035 & 55.07 & 10.48 & 40.38 & 82.90 \\
\hline & & & & & \\
\hline
\end{tabular}

Source: Author's own work.

The correlations are shown in Table 3. We acknowledge strong correlations between institutional factors (RoF, CC and GE) and amongst liquidity variables (Current_r and
Quick_r). In order to avoid multicolinearity, these variables will be included in different regression models.

Table 3: Correlation matrix

\begin{tabular}{|l|r|r|r|r|r|r|r|}
\hline Variables & (TDTA) & (TDTE) & (Current_r) & (Quick_r) & (ETR) & (FCF) & (ROA) \\
\hline TDTA & 1.000 & & & & & & \\
\hline TDTE & 0.009 & 1.000 & & & & & \\
\hline Current_r & -0.067 & -0.004 & 1.000 & & & & \\
\hline Quick_r & -0.135 & -0.004 & 0.994 & 1.000 & & & \\
\hline ETR & 0.083 & 0.025 & 0.000 & 0.005 & 1.000 & & \\
\hline FCF & -0.021 & 0.004 & -0.013 & -0.012 & -0.001 & 1.000 & \\
\hline ROA & -0.038 & 0.007 & -0.001 & 0.023 & -0.005 & 0.005 & 1.000 \\
\hline Size & 0.031 & 0.034 & -0.119 & -0.094 & -0.001 & 0.375 & -0.033 \\
\hline Growth & 0.007 & 0.005 & 0.015 & -0.013 & 0.000 & 0.011 & -0.016 \\
\hline GDP_G & -0.008 & -0.002 & 0.016 & 0.009 & -0.065 & 0.016 & 0.024 \\
\hline Inf & -0.044 & 0.023 & 0.038 & 0.019 & 0.000 & 0.025 & 0.007 \\
\hline RoF & 0.060 & -0.012 & -0.046 & -0.038 & 0.046 & 0.169 & 0.023 \\
\hline
\end{tabular}

Diana A. TOADER, Georgeta VINTILA and Stefan C. GHERGHINA (2022), Journal of Financial Studies \& Research, DOI: 10.5171/2022.572694 


\begin{tabular}{|c|c|c|c|c|c|c|c|}
\hline CC & 0.033 & 0.009 & -0.035 & -0.042 & 0.068 & 0.173 & 0.008 \\
\hline GE & 0.059 & 0.002 & 0.001 & -0.048 & 0.051 & 0.127 & 0.024 \\
\hline Variables & (Size) & (Growth) & (GDP_G) & (Inf) & (RoF) & (CC) & (GE) \\
\hline Size & 1.000 & & & & & & \\
\hline Growth & 0.002 & 1.000 & & & & & \\
\hline GDP_G & -0.014 & 0.030 & 1.000 & & & & \\
\hline Inf & -0.024 & 0.018 & 0.095 & 1.000 & & & \\
\hline RoF & 0.062 & 0.038 & -0.133 & -0.255 & 1.000 & & \\
\hline CC & 0.026 & 0.032 & -0.073 & -0.070 & 0.822 & 1.000 & \\
\hline GE & 0.002 & 0.017 & -0.155 & -0.223 & 0.474 & 0.656 & 1.000 \\
\hline
\end{tabular}

Source: Author's own work

\section{Panel regression analysis}

The results of panel data estimation for the first leverage measure are displayed in
Table 4. R-squared values indicate a low significance level of these models, due to low number of selected variables.

Table 4: The outcomes of panel data estimation for Total Debt/Total Assets

\begin{tabular}{|c|c|c|c|c|c|c|}
\hline VARIABLES & $(1)$ & $(2)$ & (3) & $(4)$ & (5) & (6) \\
\hline \multirow[t]{2}{*}{$\mathrm{ROA}$} & -0.0233 & -0.0255 & -0.0388 & & & -0.0459 \\
\hline & $(0.0496)$ & $(0.0498)$ & $(0.0505)$ & & & $(0.0490)$ \\
\hline \multirow[t]{2}{*}{ FCF } & $-0.000194^{* * *}$ & $-0.000213^{* * *}$ & & $-6.01 e-05$ & $-0.000216^{* * *}$ & \\
\hline & $(5.64 \mathrm{e}-05)$ & $(5.66 \mathrm{e}-05)$ & & $(5.11 \mathrm{e}-05)$ & $(5.64 \mathrm{e}-05)$ & \\
\hline \multirow[t]{2}{*}{ ETR } & $0.00852^{* * *}$ & $0.00817^{* * *}$ & $0.00785^{* * *}$ & $0.00855^{* * *}$ & $0.00831^{* * *}$ & $0.00800^{* * *}$ \\
\hline & $(0.00260)$ & $(0.00261)$ & $(0.00265)$ & $(0.00262)$ & $(0.00260)$ & $(0.00258)$ \\
\hline \multirow[t]{2}{*}{ Size } & $0.0168^{* * *}$ & $0.0181^{* * *}$ & $0.0152^{* * *}$ & & $0.0182^{* * *}$ & $0.0111^{* * *}$ \\
\hline & $(0.00314)$ & $(0.00313)$ & $(0.00281)$ & & $(0.00312)$ & $(0.00279)$ \\
\hline \multirow[t]{2}{*}{ Growth } & 0.00156 & 0.00125 & 0.00155 & 0.00178 & & \\
\hline & $(0.00155)$ & $(0.00155)$ & $(0.00158)$ & $(0.00156)$ & & \\
\hline \multirow[t]{2}{*}{ GDP_G } & -0.000564 & -0.000612 & 0.000194 & -0.000589 & & \\
\hline & $(0.00122)$ & $(0.00122)$ & $(0.00125)$ & $(0.00123)$ & & \\
\hline \multirow[t]{2}{*}{ Inf } & 0.00132 & 0.000998 & 0.00234 & & 0.000970 & $0.00249 *$ \\
\hline & $(0.00147)$ & $(0.00145)$ & $(0.00151)$ & & $(0.00145)$ & $(0.00147)$ \\
\hline \multirow[t]{2}{*}{ RoF } & 0.000753 & & & 0.000774 & & \\
\hline & $(0.000604)$ & & & $(0.000600)$ & & \\
\hline \multirow[t]{2}{*}{ Current_r } & $-0.00599^{* * *}$ & & & $-0.00674^{* * *}$ & & $-0.00589 * * *$ \\
\hline & $(0.000728)$ & & & $(0.000721)$ & & $(0.000725)$ \\
\hline \multirow[t]{2}{*}{$\mathrm{CC}$} & & $0.00205^{* * *}$ & & & $0.00206^{* * *}$ & \\
\hline & & $(0.000776)$ & & & $(0.000774)$ & \\
\hline \multirow[t]{2}{*}{ Quick_r } & & $-0.00536^{* * *}$ & & & $-0.00536^{* * *}$ & \\
\hline & & $(0.000745)$ & & & $(0.000744)$ & \\
\hline \multirow[t]{2}{*}{$\mathrm{GE}$} & & & $0.00232^{* * *}$ & & & $0.00203^{* * *}$ \\
\hline & & & $(0.000441)$ & & & $(0.000428)$ \\
\hline \multirow[t]{2}{*}{ Constant } & $0.0689 *$ & -0.00758 & -0.0338 & $0.137^{* * *}$ & -0.0118 & 0.0174 \\
\hline & $(0.0393)$ & $(0.0444)$ & $(0.0281)$ & $(0.0365)$ & $(0.0441)$ & $(0.0273)$ \\
\hline Observations & 1,278 & 1,278 & 1,278 & 1,278 & 1,278 & 1,278 \\
\hline R-squared & 0.097 & 0.091 & 0.057 & 0.076 & 0.090 & 0.103 \\
\hline F-statistic & $15.15^{* * *}$ & $14.04^{* * *}$ & $11.03^{* * *}$ & $17.33^{* * *}$ & $20.89^{* * *}$ & $24.39 * * *$ \\
\hline
\end{tabular}

Source: Author's own work. Figures in brackets represent standard errors; ${ }^{*},{ }^{* *},{ }^{* * *}$ denote the level of significance of $10 \% ; 5 \%$ and $1 \%$ respectively. 
These results show that ROA, Growth, GDP growth, inflation and rule of law have an insignificant impact on the dependent variable. Between the effective tax rate and total debt to total assets exists a positive significant association (Antoniou et al. 2008; Graham, 1996), consistent with Trade off theory. The coefficients of current and quick ratio are negative and significant (Eriotis et al. 2007; Eldomiaty, 2007), consistent with pecking order theory. Between size and dependent variable exists a positive significant relationship, consistent with trade-off theory (Ezeoha et al. 2008), suggesting that bigger companies finance their investments through debt.
Free cash flow has a negative significant impact on total debt to total assets variable. Control of corruption and government effectiveness have a direct significant impact on debt ratio. Nguyen and Tran (2017) obtained a negative significant relationship between control of corruption and leverage, but a positive significant relationship between rule of law, government effectiveness and leverage.

The results of panel data estimation for the next leverage measure are displayed in Table 5. R-squared values keep their low significance level.

Table 5: The outcomes of panel data estimation for Total Debt/Total Equity

\begin{tabular}{|c|c|c|c|c|c|c|}
\hline VARIABLES & (1) & (2) & (3) & (4) & (5) & (6) \\
\hline \multirow[t]{2}{*}{ ROA } & $-2.055^{* * *}$ & $-2.063^{* * *}$ & $-2.093^{* * *}$ & & & $-2.098^{* * *}$ \\
\hline & $(0.251)$ & $(0.250)$ & $(0.251)$ & & & $(0.248)$ \\
\hline \multirow[t]{2}{*}{ FCF } & $-0.000574^{* *}$ & $\begin{array}{c}- \\
0.000638^{* *}\end{array}$ & & -0.000147 & $-0.000785^{* * *}$ & \\
\hline & $(0.000285)$ & $(0.000285)$ & & $(0.000265)$ & $(0.000291)$ & \\
\hline \multirow[t]{2}{*}{ ETR } & $0.0333^{* *}$ & $0.0312^{* *}$ & $0.0318^{* *}$ & $0.0374^{* * *}$ & $0.0357^{* * *}$ & $0.0318^{* *}$ \\
\hline & $(0.0131)$ & $(0.0131)$ & $(0.0132)$ & $(0.0136)$ & $(0.0134)$ & $(0.0131)$ \\
\hline \multirow[t]{2}{*}{ Size } & $0.0616^{* * *}$ & $0.0648^{* * *}$ & $0.0573^{* * *}$ & & $0.0730^{* * *}$ & $0.0470^{* * *}$ \\
\hline & $(0.0159)$ & $(0.0157)$ & $(0.0140)$ & & $(0.0161)$ & $(0.0141)$ \\
\hline \multirow[t]{2}{*}{ Growth } & 0.000351 & -0.000197 & 0.00103 & 0.00165 & & \\
\hline & $(0.00782)$ & $(0.00781)$ & $(0.00783)$ & $(0.00810)$ & & \\
\hline \multirow[t]{2}{*}{ GDP_G } & 0.00161 & 0.000827 & 0.00386 & -0.00250 & & \\
\hline & $(0.00618)$ & $(0.00616)$ & $(0.00623)$ & $(0.00637)$ & & \\
\hline \multirow[t]{2}{*}{ Inf } & $0.0235^{* * *}$ & $0.0195^{* * *}$ & $0.0261^{* * *}$ & & $0.0186^{* *}$ & $0.0265^{* * *}$ \\
\hline & $(0.00744)$ & $(0.00732)$ & $(0.00751)$ & & $(0.00749)$ & $(0.00745)$ \\
\hline \multirow[t]{2}{*}{ RoF } & $0.00942^{* * *}$ & & & $0.00713^{* *}$ & & \\
\hline & $(0.00305)$ & & & $(0.00311)$ & & \\
\hline \multirow[t]{2}{*}{ Current_r } & $-0.0151^{* * *}$ & & & $-0.0172^{* * *}$ & & $-0.0146^{* * *}$ \\
\hline & $(0.00368)$ & & & $(0.00374)$ & & $(0.00367)$ \\
\hline \multirow[t]{2}{*}{$\mathrm{CC}$} & & $0.0162^{* * *}$ & & & $0.0147^{* * *}$ & \\
\hline & & $(0.00391)$ & & & $(0.00400)$ & \\
\hline \multirow[t]{2}{*}{ Quick_r } & & $-0.0136^{* * *}$ & & & $-0.0127^{* * *}$ & \\
\hline & & $(0.00375)$ & & & $(0.00384)$ & \\
\hline \multirow[t]{2}{*}{ GE } & & & $0.0103^{* * *}$ & & & $0.00940^{* * *}$ \\
\hline & & & $(0.00219)$ & & & $(0.00217)$ \\
\hline \multirow[t]{2}{*}{ Constant } & $-0.357^{*}$ & $-0.691^{* * *}$ & $-0.414^{* * *}$ & -0.00329 & $-0.760 * * *$ & $-0.269^{*}$ \\
\hline & $(0.199)$ & $(0.224)$ & $(0.139)$ & $(0.189)$ & $(0.228)$ & $(0.138)$ \\
\hline Observations & 1,278 & 1,278 & 1,278 & 1,278 & 1,278 & 1,278 \\
\hline R-squared & 0.096 & 0.099 & 0.090 & 0.028 & 0.051 & 0.101 \\
\hline F-statistic & $15.00^{* * *}$ & $15.52^{* * *}$ & $17.98^{* * *}$ & $6.12^{* * *}$ & $11.32^{* * *}$ & $23.84^{* * *}$ \\
\hline
\end{tabular}

Source: Author's own work. Figures in brackets represent standard errors; ${ }^{*},{ }^{* *},{ }^{* * *}$ denote the level of significance of $10 \% ; 5 \%$ and $1 \%$ respectively.

In these models, ROA variable becomes significant and is negatively associated with our dependent variable (Fama and French,
2002; Moradi and Paulet, 2019), consistent with pecking order theory. Growth and gross domestic product growth still have an 
insignificant impact. Inflation variable becomes significant and has a positive coefficient (Demirguc-Kunt and Maksimovic, 1998). Liquidity variables and free cash flow haven't changed their significance and their inverse relationship with total debt to equity. Size variable keeps its positive impact on this second leverage measure. Rule of law has a positive and significant coefficient, similar to the control of corruption and government effectiveness. Bolaji et al. (2019) identified a positive relationship between these three variables and leverage.

\section{Conclusions}

This paper explores the determinants on capital structure choices of 152 nonfinancial companies from three emergent countries: Romania, Bulgaria and Hungary, over the period 1996-2020. This empirical study contains two leverage measures as dependent variables: total debt to total assets and total debt to equity. As explanatory variables, we have three categories, namely: firm-specific characteristics, country-specific, and insitutional factors.

The findings of this study are similar to other research papers. The behaviour of companies is more consistent with pecking order theory, as liquidity and profitability have an inverse relationship with both dependent variables. This suggests that firms prefer with priority to use internal funds to finance their investments. The mean value of total debt to equity is approximatively 25 percent; companies choose to finance through the banking system also to benefit from tax deductibility of interest expenses, as we can see that the effective tax rate has a positive and significant impact on debt. In contrast to other papers, gross domestic product growth is insignificant, but inflation is positive and significant. This suggests that companies are not afraid to contract loans even though the borrowing costs are increasing. Institutional factors, rule of law, control of corruption and government effectiveness, have a direct impact on leverage. If policies and institutions are well developed and strong, this offers creditors, shareholders and companies more confidence to finance or to be financed through debt and equity issuance.

The paper has limitations. The main focus is on debt structure through two relevant leverage measures, but it is important to take into consideration debt maturity. Moreover, our paper uses two-stage ordinary squares, but it doesn't eliminate the problem of endogeneity and heterogenity. Future research may use other model estimations and may include more variables, both dependent and independent.

\section{Acknowledgment}

"This paper was co-financed by The Bucharest University of Economic Studies during the PhD program."

\section{References}

- Amidu, M. (2007), 'Determinants of capital structure of banks in Ghana: an empirical approach', Baltic Journal of Management, 2(1), 67-79.

- $\quad$ Antoniou, A., Guney, Y., and Paudyal, K. (2008), 'The determinants of capital structure: capital market-oriented versus bank-oriented institutions', Journal of Financial and Quantitative Analysis, 43(1), 59-92.

- Baker, M., and Wurgler, J. (2002), 'Market timing and capital structure', The Journal of Finance, 57(1), 1-32.

- Bolaji, T., Bany-Ariffin, A., and AzmanSaini, W. (2019), 'Impact of institutional quality on the capital structure of firms in developing countries', Emerging Markets Review, 39, 175-209.

- Booth, L., Aivazian, V., Demirguc-Kunt, A., and V., M. (2001), 'Capital structures in developing countries', The Journal of Finance, LVI(1), 87-130.

- Bradley, M., Jarrel, G., and Kim, E. (1984), 'On the existence of an optimal capital structure: theory and evidence', The Journal of Finance, 39(3), 857-878.

- $\quad$ Brounen, D., De Jong, A., and Koedijk, K. (2006), 'Capital structure policies in Europe: survey evidence', Journal of Banking and Finance, 30(5), 14091442. 
- Chen, J.J., (2004), 'Determinants of capital structure of Chinese-listed companies', Journal of Business Research, 57(12), 1341-1351.

- $\quad$ Cheng, S., and Shiu, C. (2007), 'Investor protection and capital structure: International evidence', Journal of Multinational Financial Management, 17(1), 30-44.

- De Jong, A., Kabir, R., and Nguyen, T. (2008), 'Capital structure around the world: the roles of firm and countryspecific determinants', Journal of Banking \& Finance, 32(9), 1954-1969.

- DeAngelo, H., and Masulis, R. (1980), 'Optimal capital structure under corporate and personal taxation', Journal of Financial Economics, 8(1), 3-29.

- Deloof, M., and Overfelt, W. (2008), 'Were modern capital structure theories valid in Belgium before World War I?', Journal of Business Finance \& Accounting, 35(3/4), 491-515.

- Demirguc-Kunt, A., and Maksimovic, V. (1998),' Law, finance and firm growth', The Journal of Finance, 53(6), 21072137.

- $\quad$ Eldomiaty, T. (2007), 'Determinants of corporate capital structure: evidence from an emerging economy', International Journal of Commerce and Management, 17(1/2), 25-43.

- Eldomiaty, T., and Azim, M. (2008), 'The dynamics of capital structure and heterogeneous systematic risk classes in Egypt', International Journal of Emerging Markets, 3(1), 7-37.

- Eriotis, N., Vasiliou, D., and VentouraNeokosmidi, Z. (2007), 'How firm characteristics affect capital structure: an empirical study', Managerial Finance, 33(5), 321-331.

- Ezeoha, A. (2008), 'Firm size and corporate financial-leverage choice in a developing economy evidence from Nigeria', The Journal of Risk Finance, 9(4), 351-364.

- Ezeoha, A. (2011), 'Firm versus industry financing structures in Nigeria', African Journal of Economic and Management Studies, 2(1), 42-55.

- Fama, E., and French, K. (2002), 'Testing tradeoff and pecking order predictions about dividends and debt',
Review of Financial Studies, 15(1), 133.

- Fan, J., Titman, S., and Twite, G. (2012), 'An international comparison of capital structure and debt maturity choices', Journal of Financial Quantitative Analysis, 47, 23-56.

- Frank, M., and Goyal, V. (2003), 'Testing the pecking order theory of capital structure', Journal of Financial Economics, 67, 217-248.

- Frank, M., and Goyal, V. (2009), 'Capital structure decisions: which factors are reliably important?', Financial Management, 38(1), 1-37.

- Giannetti, M. (2003), 'Do better institutions mitigate agency problems? Evidence from corporate finance choices', Journal of Financial and Quantitative Analysis, 38(1), 185212.

- Goyenko, R., Holden, C., and Trzcinka, C. (2009), 'Do liquidity measures measure liquidity?', Journal of Financial Economics, 92(2), 153-181.

- Graham, J. (1996), 'Debt and the marginal tax rate', Journal of Financial Economics, 41(1), 41-73.

- Harris, C., and Roark, S. (2019), 'Cash flow risk and capital structure decisions', Finance Research Letters, 29(3), 393397.

- Heshmati, A. (2001), 'The dynamics of capital structure: evidence from Swedish micro and small firms', Research in Banking and Finance, 2(1), 199-241.

- Huang, G., and Song, F. (2006), 'The determinants of capital structure: evidence from China', China Economic Review, 17(1), 14-36.

- Jensen, M., and Meckling, W. (1976), 'Theory of the firm: managerial behavior, agency costs and ownership structure', Journal of Financial Economics, 3(4), 305-360.

- Jong, A., Kabir, R., and Nguyen, T. (2008), 'Capital structure around the world: The roles of firm-and countryspecific determinants', Journal of Banking and Finance, 32(9), 19541969.

- Jordan, J., Lowe, J., and Taylor, P. (1998), 'Strategy and financial policy 
in UK small firms', Journal of Business Finance and Accounting, 25(1), 1-27.

- Kane, A., Marcus, A., and McDonald, R. (1984), 'How big is the tax advantage to debt?', Journal of Finance, 39(3), 841-853.

- Karadeniz, E., Kandir, S., Balcilar, M., and Onal, Y. (2009), 'Determinants of capital structure: evidence from Turkish lodging companies', International Journal of Contemporary Hospitality Management, 21(5), 594609.

- $\quad$ Khemiri, W., and Noubbigh, H. (2018), 'Determinants of capital structure: evidence from sub-Saharan African firms', The Quarterly Review of Economics and Finance, 70(11), 150159.

- Kraus, A., and Litzenberger, R. (1973), 'A state-preference model of optimal financial leverage', Journal of Finance, 28(4), 911-922.

- La Porta, R., Lopez-De-Silanes, F., Shleifer, A., and Vishny, R. (1998), 'Law and Finance', Journal of Polical Economy, 106(6).

- Lemmon, M., and Zender, J. (2010), 'Debt capacity and tests of capital structure theories', Journal of Financial and Quantitative Analysis, 45(5), 1161-1187.

- Margaritis, D., and Psillaki, M. (2007), 'Capital structure and firm efficiency', Journal of Business Finance \& Accounting, 34, 1447-1469.

- Marsh, P. (1982), 'The choice between debt and equity: an empirical study', Journal of Finance, 37(1), 121-144.

- Mazur, K. (2007), 'The determinants of capital structure choice: evidence from Polish companies', International Advances in Economic Research, 13(4), 495-514.

- Modigliani, F., and Miller, M. (1958), 'The cost of capital, corporation finance and the theory of investment', The American Economic Review, 48(3), 261-297.

- Modigliani, F., and Miller, M. (1963), 'Corporate income taxes and the cost of capital: a correction', American Economic Review, 53(3), 433-443.

- Moradi, A., and Paulet, E. (2019), 'The firm-specific determinants of capital
structure-An empirical analysis of firms before and during the Euro Crisis', Research in International Business and Finance, 47(1), 150-161.

- Myers, S. (2001), 'Capital structure', The Journal of Economic Perspectives, 15(2), 81-102.

- Myers, S., and Majluf, N. (1984), 'Corporate financing and investment decisions when firms have information that investors do not have', Journal of Financial Economics, 13(2), 187-221.

- Nguyen, H., and Tran, T. (2017), 'Institutional Quality Matters and Vietnamese Corporate Debt Maturity', Journal of Science: Economics and Business, 33(5), 26-39.

- Ooi, J. (1999), 'The determinants of capital structure: evidence on UK property companies', Journal of Property Investment \& Finance, 6(3), 464-480.

- Qian, J., and Strahan, P. (2007), 'How Laws and Institutions Shape Financial Contracts: The Case of Bank Loans', The Journal of Finance, 62, 2803-2834.

- Rajan, R. G., and Zingales, L. (1995), 'What do we know about capital structure? Some evidence from international data', The Journal of Finance, 50(5), 1421-1460.

- $\quad$ Ross, S. (1977), 'The determination of financial structure: the incentivesignalling approach', The Bell Journal of Economics, 8(1), 23-40.

- $\quad$ Stiglitz, J. (1973), 'Taxation, corporate financial policy and the cost of capital', Journal of Public Economics, 2(1), 134.

- $\quad$ Titman, S., and Wessels, R. (1988), 'The determinants of capital structure choice', Journal of Finance, 43(1), 1-19.

- Viviani, J. (2008), 'Capital structure determinants: an empirical study of French companies in the wine industry', International Journal of Wine Business Research, 20(2), 171194.

- Vo, X. (2017), 'Determinants of capital structure in emerging markets: evidence from Vietnam', Research in International Business and Finance, 40(4), 105-113. 